\title{
Biosynthesis of 3'-Deoxy-carbamoylkanamycin C in a Streptomyces tenebrarius Mutant Strain by tacB Gene Disruption
}

\author{
Yonghong Yu, Xifan Hou, Xianpu Ni, Huanzhang Xia
}

Received: July 11, 2007 / Accepted: February 1, 2008

(C) Japan Antibiotics Research Association

\begin{abstract}
Streptomyces tenebrarius H6 mainly produces three kinds of antibiotics: apramycin, carbamoyltobramycin and some carbamoylkanamycin B. In our present study, a dehydrogenase gene $\operatorname{tac} B$ in the tobramycin biosynthetic gene cluster was disrupted by in-frame deletion. The result of TLC bio-autograph analysis demonstrated the disruption mutant strain produced apramycin and a new antibiotic. The new antibiotic was identified as $3^{\prime}$-deoxycarbamoylkanamycin $\mathrm{C}$ by MS and NMR analysis after isolation and purification. The disruption mutant was restored to produce carbamoyltobramycin in a complementation experiment by the intact $t a c B$ gene. Our studies suggested that the $\operatorname{tac} B$ gene encodes a $6^{\prime}$ dehydrogenase, which reduces the $6^{\prime}$-hydroxyl group of paromamine to a keto group, thus facilitating the transfer of an aminogroup to form neamine. This study is the first report on the generation of a tobramycin derivative by gene engineering, and will contribute to clarify the complete biosynthetic pathway of tobramycin.
\end{abstract}

Keywords Streptomyces tenebrarius, in-frame deletion, complementation, $\quad 6^{\prime}$-dehydrogenase, $\quad 3$ '-deoxycarbamoylkanamycin $\mathrm{C}$

\section{Introduction}

Aminoglycosides are one of the most important antibiotic

H. Xia (Corresponding author), Y. Yu, X. Hou, X. Ni: The School of Life Science and Biopharmaceutics, Shenyang Pharmaceutical University, Shenyang, Liaoning 110016, China, E-mail: xiahz612@sina.com families applied for clinical purpose. It have a wide antibacterial spectrum and special antibacterial activity against aerobic gram negative bacilli. However its main side-effects as ototoxicity and nephrotoxicity [1] and bacterial drug resistances compromise its clinical usage. This has necessitated the development of structural novel and more potent antibiotics. Based on chemical structure, aminoglycosides can be classified into two major groups: one has an aglycone fully-substituted aminocyclitol which is synthesized from myo-inositol [2]. The other group has a common aglycone of 2-deoxystreptamine (2-DOS). Many important aminoglycosides belong to the second category, such as tobramycin, kanamycin and neomycin.

Compared with other major classes of antibiotics such as macrolides, studies on the biosynthesis of aminoglycosides have fallen behind but in recent years, several gene clusters of 2-deoxystreptamin-containing aminoglycosides have been cloned. Yasumasa Ota et al. [3] first reported the gene cluster of Butirosin, identified the function of BtrC which catalyzes the carbocycle formation from D-glucose-6phosphate to 2-deoxy-scyllo-inosose (2-DOI) in vivo. And then partial biosynthetic gene clusters of tobramycin, gentamycin, kanamycin, neomycin and ribostamycin were cloned from different strains [4 9]. All these papers proposed the same biosynthetic pathway of 2-DOS, and most genes encoding for enzymes catalyzing each step of 2-DOS biosynthesis have been discovered [3 11]. Finally pseudodisaccharide intermediate paromamine is produced through the addition of dTDP-glucosamine to 2-DOS with the help of glycosyltransferase.

There are several dehydrogenases in the gene cluster of tobramycin, but only the function of TbmA (2-DOI synthase) was demonstrated [4]. In this paper, we explored the function of $\operatorname{tac} B$ gene which located in tobramycin 
biosynthetic gene cluster. Based on gene disruption and complementation experiments, along with the structure analysis of the new antibiotic produced by the $\operatorname{tac} B$ disruption mutant, our studies suggest that the $\operatorname{tac} B$ gene encodes a 6'-dehydrogenase, which catalyzed the $6^{\prime}$ hydroxyl group of paromamine to form a keto group. This is the first report on blocking tobramycin derivative biosynthesis due to the ceased expression of a dehydrogenase gene in context with the $t a c B$ disruption.

\section{Materials and Methods}

\section{General}

Methods for isolation and manipulation of DNA were used as described by Sambrook et al. [13]. Transformation of Escherichia coli followed the $\mathrm{CaCl}_{2}$ method [13]. Conjugation transformation of Streptomyces tenebrarius H6 was performed according to the method described previously [14]. The reference substance 3'-deoxycarbamoylkanamycin C (M.W.=511.2) was generated from a mutagenesis strain [16] and purified in our laboratory. Ion-exchange resins were purchased from Shanghai Huazhen Co. Ltd.

\section{Strains, Plasmids and Culture Conditions}

Bacterial strains and plasmids used in the study are listed in Table 1. Agar medium (SM) was used for the $S$. tenebrarius H6 sporulation [17] and MS [15] for the conjugation between $S$. tenebrarius $\mathrm{H} 6$ and E. coli ET12567 (pUZ8002). Liquid medium (SGGP) was used for $S$. tenebrarius $\mathrm{H} 6$ or mutant strains mycelium growth. For antibiotics production in S. tenebrarius $\mathrm{H} 6$ or mutant strains, fermentation was carried out by using seed culture medium and fermentation medium [17]. $2 \times$ YT medium used in conjugation was prepared as described by Hopwood et al. [15]. If necessary, erythromycin was added at a concentration of $100 \mu \mathrm{g} / \mathrm{ml}$. E. coli strains were grown in Luria-Bertani (LB) medium at $37^{\circ} \mathrm{C}$, supplemented with $50 \mu \mathrm{g} / \mathrm{ml}$ apramycin, $50 \mu \mathrm{g} / \mathrm{ml}$ ampicillin, $25 \mu \mathrm{g} / \mathrm{ml}$ chloromycetin or $25 \mu \mathrm{g} / \mathrm{ml}$ kanamycin when necessary. Bacillus subtilis was incubated in bioassay medium [17].

\section{Gene Disruption}

The recombinant plasmid was constructed for targeted disruption of $t a c B$ as follows: A $2.15-\mathrm{kb}$ fragment containing $t a c B$ gene was amplified from wild-type $S$. tenebrarius $\mathrm{H6}$ genomic DNA with primer 1 (CATAAGCTTCAGCCCGAGGACACGC) and primer 3 (GCGCTCTAGATGACCGTCTCCAAGGG). PCR condition was $95^{\circ} \mathrm{C}, 5$ minutes for denaturation, 30 cycles of $94^{\circ} \mathrm{C}, 2$ minutes, $59^{\circ} \mathrm{C}, 30$ seconds, $72^{\circ} \mathrm{C}, 2.5$ minutes for extension of DNA. The amplified PCR product was purified, digested with HindIII and $X b a \mathrm{I}$ and cloned into the same site of pIJ2925 to yield pSPU501. The SalI-SalI fragment internal to $\operatorname{tac} B$ was released and self-ligated as to construct an in-frame disrupted $t a c B$ gene named $\triangle t a c B$. And then, the erythromycin-resistant gene (ermE) fragment from plasmid pWHM2 was inserted into the KpnI site. The resulting $\triangle t a c B$-ermE fragment was excised with $B g l I I$ and cloned into the BamHI site of pHZ132 [18] to create pHZ$\Delta t a c B$, which was transferred into E. coli ET12567

Table 1 Bacterial strains and plasmids used in this study

\begin{tabular}{|c|c|c|}
\hline Strains or plasmids & Relevant features* & $\begin{array}{l}\text { Source or } \\
\text { reference }\end{array}$ \\
\hline \multicolumn{3}{|l|}{ Strains } \\
\hline Streptomyces tenebrarius $\mathrm{H} 6$ & Wild type, carbamoyltobramycin producer & This lab \\
\hline S. tenebrarius tac $B^{-}$ & Disrupted in tacB & This work \\
\hline S. tenebrarius tac $B^{-}-\operatorname{tac} B$ & Complement intact tacB; Ery $^{\mathrm{R}}$ & This work \\
\hline Escherichia coli ET12567 (pUZ8002) & Strain used in E.coli-Streptomyces conjugation & 15 \\
\hline \multicolumn{3}{|l|}{ Plasmids } \\
\hline pHZ132 & E. coli-Streptomyces shuttle vector used for gene inactivation; $\mathrm{Am}^{\mathrm{R}}$ & 18 \\
\hline pSPU227 & Expressive vector containing Pmer promoter+to terminator; $\mathrm{Am}^{\mathrm{R}}$ & This lab \\
\hline pWHM2 & $\begin{array}{l}\text { Erythromycin-resistant gene ermE in 1.7-kb Kpnl fragment used as } \\
\text { selective marker; } \mathrm{Am}^{\mathrm{R}}\end{array}$ & 25 \\
\hline pSET152 & Integrative (suicide) vector for gene complementation; $A p^{R}$ & 19 \\
\hline $\mathrm{pHZ}-\Delta \operatorname{tac} B$ & $\mathrm{pHZ132}$ derivative containing $\Delta \operatorname{tac} B+e r m E ; \mathrm{Am}^{\mathrm{R}}$ & This work \\
\hline pSET-tacB & pSET152 derivative containing Pmer+tacB+to+ermE; $A p^{R}$ & This work \\
\hline
\end{tabular}

${ }^{*} A m^{R}$, ampicillin resistant; $A p^{R}$, apramycin resistant; Ery ${ }^{R}$, erythromycin resistant. 
(pUZ8002).

Plasmid pHZ- $\Delta$ tacB was introduced into $S$. tenebrarius H6 by conjugation, which was carried out on MS medium at $28^{\circ} \mathrm{C}$ for 20 hours. After overlaying with erythromycin $(100 \mu \mathrm{g} / \mathrm{ml})$ and nalidixic acid $(50 \mu \mathrm{g} / \mathrm{ml})$, incubation was continued at $28^{\circ} \mathrm{C}$ for $7 \sim 9$ days. Single-crossover exconjugants of $S$. tenebrarius $\mathrm{H} 6$ were obtained using erythromycin as a selective marker. After three rounds of sporulation in the absence of erythromycin, two types of erythromycin-sensitive strains, namely tacB-disruptants and wild-type revertants, were obtained for detection of antibiotic products. To confirm the double-crossover integration of $\triangle t a c B$ into the $t a c B$ locus, genomic DNA of exconjugant was isolated, and PCR was carried out using primers 1 and 3, the amplification product was subjected to sequencing analysis, and the result was compared with the sequence of $\operatorname{tac} B$ in the Genbank.

\section{Complementation of $t a c B$ in the Gene Disruption Mutant}

To complement the $t a c B$ disruption mutant, the intact $\operatorname{tac} B$ gene was amplified from the genomic DNA of S. tenebrarius H6 with primer a (GGGACGGTCTAGAATGCTGCTGATCTCAG) and primer b (CATAAGCTTCAGCCCGAGGACACGC). The amplified fragment was

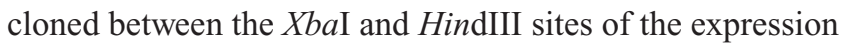
plasmid pSPU227. The BglII fragment containing Pmer+tacB+to was inserted into the BamHI site of pIJ2925, and the ermE gene was sub-cloned as a KpnI fragment into the same plasmid. The resulting Pmer + tacB + to + ermE fragment was excised with $B g l \mathrm{II}$ and cloned into the BamHI site of pSET152 [19], resulting in the final plasmid pSET152-tacB.

pSET152-tacB was introduced into the $t a c B$ disrupted mutant strain by conjugation from E. coli ET12567 (pUZ8002). The erythromycin-resistant $\left(\right.$ Ery $\left.^{\mathrm{R}}\right)$ exconjugants were selected for detection of antibiotic products.

\section{Analysis of Antibiotics by TLC and Bio-autography}

The fermentation filtrates of the $t a c B$ disruption mutants, the $\operatorname{tac} B$ complementary colonies $\left(\right.$ Ery $\left.^{\mathrm{R}}\right)$ or $S$. tenebrarius $\mathrm{H} 6$ were applied to silica $\mathrm{GF}_{254}$ TLC glass plate (Huiyou, China), and developed with a solvent system of $\mathrm{PrOH}: \mathrm{MeOH}:$ ammonia solution $(25 \%)=25: 20: 23$ at $37^{\circ} \mathrm{C}$ for 3.5 hours, then the plate was placed on agar medium seeded with $B$. subtilis for 10 minutes, and the TLC plate was removed finally the agar medium was incubated overnight at $37^{\circ} \mathrm{C}$.

\section{Purification and Identification of the New Antibiotic}

The antibiotic products of wild-type strain, $\operatorname{tac} B$ disruption strain and complementary strain were isolated and purified following the protocols described previously $[16,20]$.

For HPLC-ELSD analysis, the method of Hong Li-ya [21] was used, in which a reverse $\mathrm{C}_{18}$ column (4.6 by $200 \mathrm{~mm}$; $5 \mu \mathrm{m}$; Diamonsil, USA), mobile phase $0.2 \mathrm{~mol} /$ liter TFA : $\mathrm{MeOH}(95: 5)$ at a flow rate of $1.0 \mathrm{ml} /$ minute was used. The drift tube temperature was $105^{\circ} \mathrm{C}$, the detector was SofTA-200S (USA). High-resolution MS was performed on a Waters Quattro micro API spectrometer (USA). The NMR data was acquired on an AV-600 (600 MHz) spectrometer.

\section{In Vitro Antibacterial Activity}

The in vitro antibacterial activities were determined by agar method as described earlier [22]. The MIC was defined as the lowest concentration of antibiotic that completely inhibited visible growth of the organism.

\section{Results and Discussion}

\section{Generation and Analysis of $\Delta t a c B$ Mutant S. tenebrarius tacB ${ }^{-}$}

In order to avoid polar effects on the downstream gene transcription, an in-frame deletion was introduced into $t a c B$. The disruption strategy was described above and illustrated in Fig. 1.

The E. coli-Streptomyces shuttle vector pHZ132 containing $\triangle t a c B$ (an internal SalI fragment was deleted) and erythromycin-resistant gene ermE was introduced into S. tenebrarius H6 by conjugation from E. coli ET12567 (pUZ8002). The erythromycin-resistant exconjugants were obtained. Following erythromycin-free cultivation for three rounds of sporulation, two types of double-crossover strains, namely $\triangle t a c B$ strains and wild-type revertant strains were obtained and then identified by PCR analysis. PCR with primer 1 and 3 produced a $2.0 \mathrm{~Kb}$ from $\triangle t a c B$ strains but not from wild-type revertant strains. Furthermore, this PCR amplification product from one $\triangle t a c B$ strain was subjected to sequencing analysis with the primer S: 5'-TTCGGCCCCGGGTGCGC-3' and the result showed that only one SalI site in $\triangle t a c B$ together with the internal 143-bp fragment was deleted. This $\triangle t a c B$ strain was named as $S$. tenebrarius $t a c B^{-}$.

The growth profile of $S$. tenebrarius $\operatorname{tac} B^{-}$in liquid medium $\mathrm{CP}$ was identical to that of the wild-type strain, while the formation of mycelia and spores was indistinguishable from that of the wild-type strain. TLC analysis of the fermentation broth showed that $S$. 


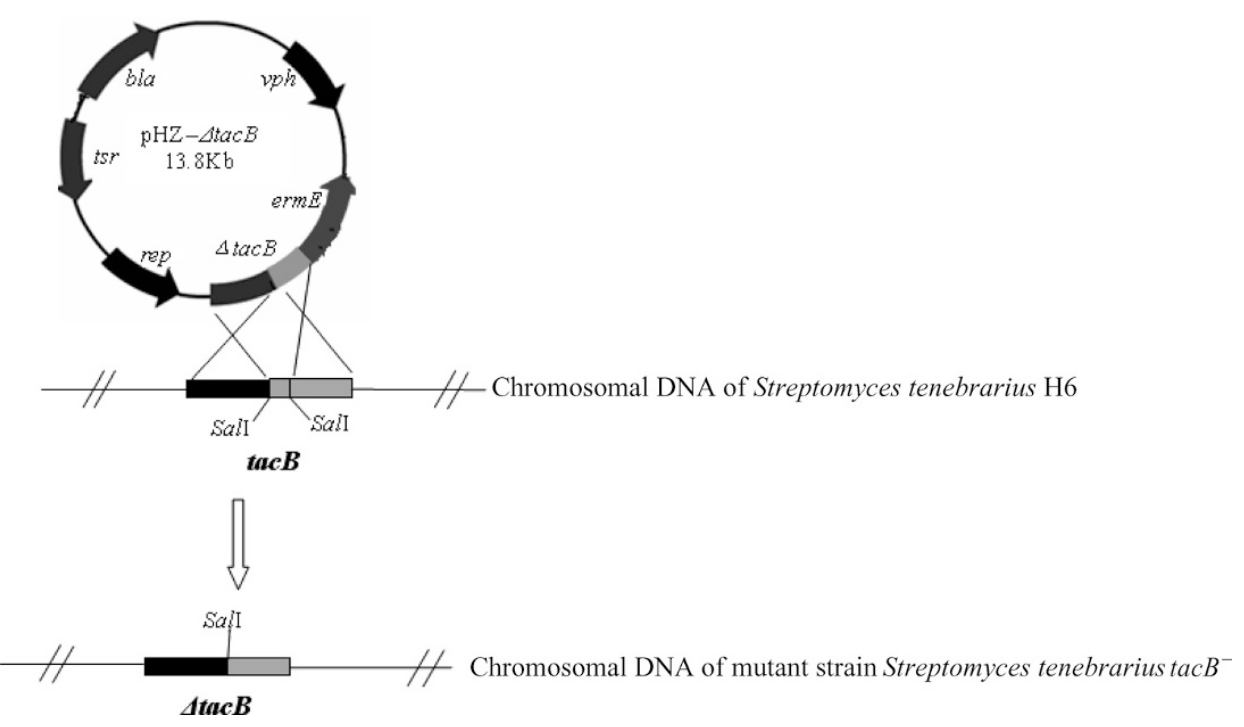

Fig. 1 The plasmid $\mathrm{pHZ}-\Delta \operatorname{tac} B$ used in conjugation and the result of in-frame deletion of tacB via double crossover (the gray part was deleted).

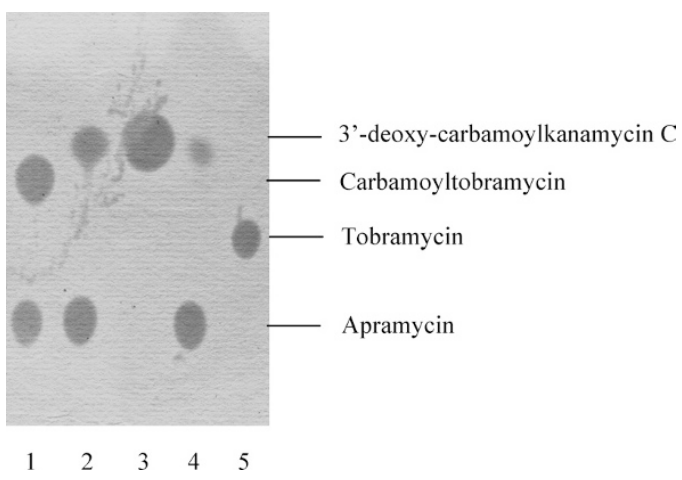

Fig. 2 TLC analysis of the fermentation broths of $S$. tenebrarius $\mathrm{H} 6$ and disruption mutants.

1, S. tenebrarius $\mathrm{H6} ; 2 \& 4$, S. tenebrarius tac $B^{-} ; 3,3^{\prime}$-deoxycarbamoylkanamycin C; 5 , tobramycin.

tenebrarius tac $B^{-}$produced a new component, whose $\mathrm{Rf}$ value was approximate to that of $3^{\prime}$-deoxycarbamoylkanamycin C [16], as shown in Fig. 2.

\section{Purification and Identification of the New Antibiotic}

To determine the structure of the new antibiotic produced by $\operatorname{tac} B$ gene disruption mutant, the antibiotic products of $S$. tenebrarius $\operatorname{tacB}^{-}$were isolated and purified. Positive ESI-MS spectrometry confirmed the presence of 3 '-deoxycarbamoylkanamycin $\mathrm{C}$ in the sample by yielding molecular ions $\left(m / e\right.$ for $\left.[\mathrm{M}+\mathrm{H}]^{+}\right)$of $512.2\left(\mathrm{C}_{19} \mathrm{H}_{37} \mathrm{~N}_{5} \mathrm{O}_{11}\right.$, calcd 511.2) [16], as show in Fig. 3.

The distinct peak at 367.2 also agrees with the mass of the sum of the DOS and 6'-carbamoyl-kanosamine. The result from NMR analysis further confirmed that this new antibiotic is $3^{\prime}$-deoxy-carbamoylkanamycin $\mathrm{C}[16,23]$. The ${ }^{13} \mathrm{C}$-NMR data of the new antibiotic was listed in Table 2 and shown in Fig. 4.

\section{Complementation of the Mutant Strain S. tenebrarius tacB ${ }^{-}$}

In order to confirm that the new antibiotic production in $S$. tenebrarius $t a c B^{-}$was due to the loss function of $\operatorname{tac} B$ and excluded the possibility of polar effects in the disruption mutant, restoration of the intact $t a c B$ gene in the $\triangle t a c B$ strain, $S$. tenebrarius $\operatorname{tac} B^{-}$was carried out.

The complementary plasmid pSET-tac $B$ was constructed as described above, in which the expression of the intact $t a c B$ gene is under the control of the mercury resistant promoter (Pmer) [24]. pSET-tacB was introduced into the disruption mutant $S$. tenebrarius $\operatorname{tac}^{-}$by conjugation, and Ery $^{\mathrm{R}}$ exconjugants were selected, named $S$. tenebrarius tac $B^{-}-t a c B$. HPLC-ELSD analysis confirmed that carbamoyltobramycin production was partially restored in $S$. tenebrarius $\operatorname{tac} B^{-}-t a c B$ in comparison with the wildtype $S$. tenebrarius $\mathrm{H} 6$ as the control, as shown in Fig. 5. This demonstrated that the production of $3^{\prime}$-deoxycarbamoylkanamycin $\mathrm{C}$ in $S$. tenebrarius $t a c B^{-}$was due to a loss of $\operatorname{tac} B$ function.

\section{In Vitro Activity}

The antibacterial activity of 3 '-deoxy-carbamoylkanamycin $\mathrm{C}$ against several bacterial is presented in Table 3. The result showed that $3^{\prime}$-deoxy-carbamoylkanamycin $\mathrm{C}$ has antibacterial activity to commonly encountered and some 


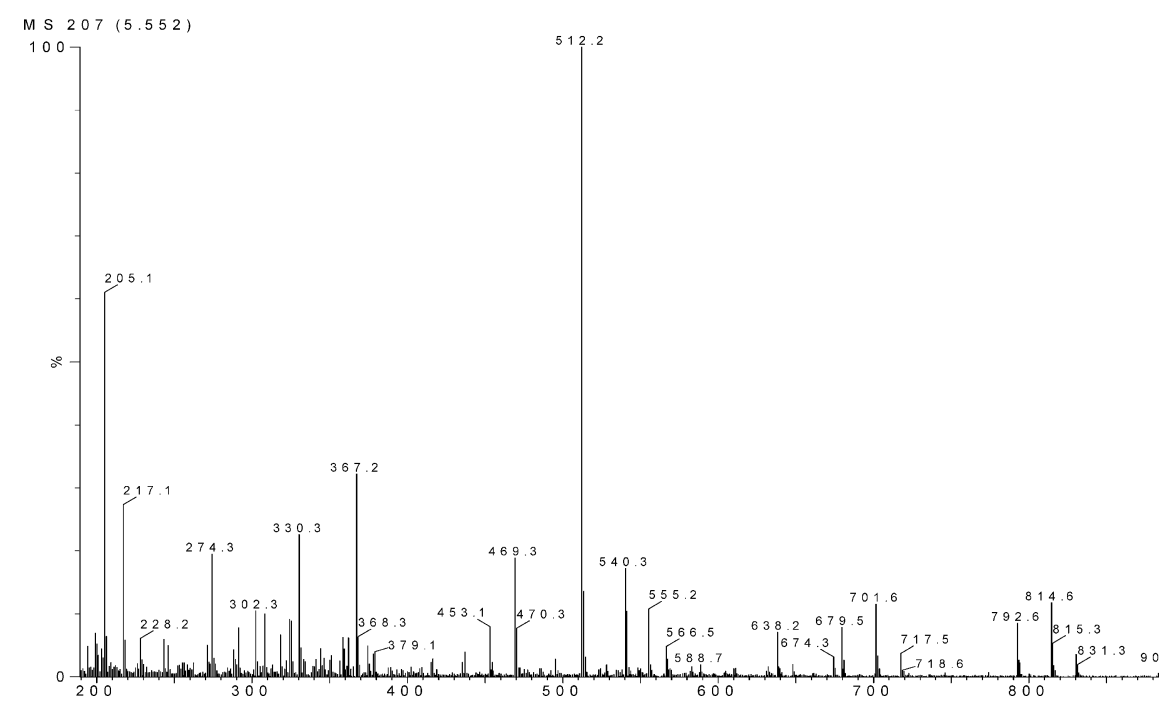

Fig. 3 Mass spectrum of the sample of $S$. tenebrarius tac $B^{-}$.

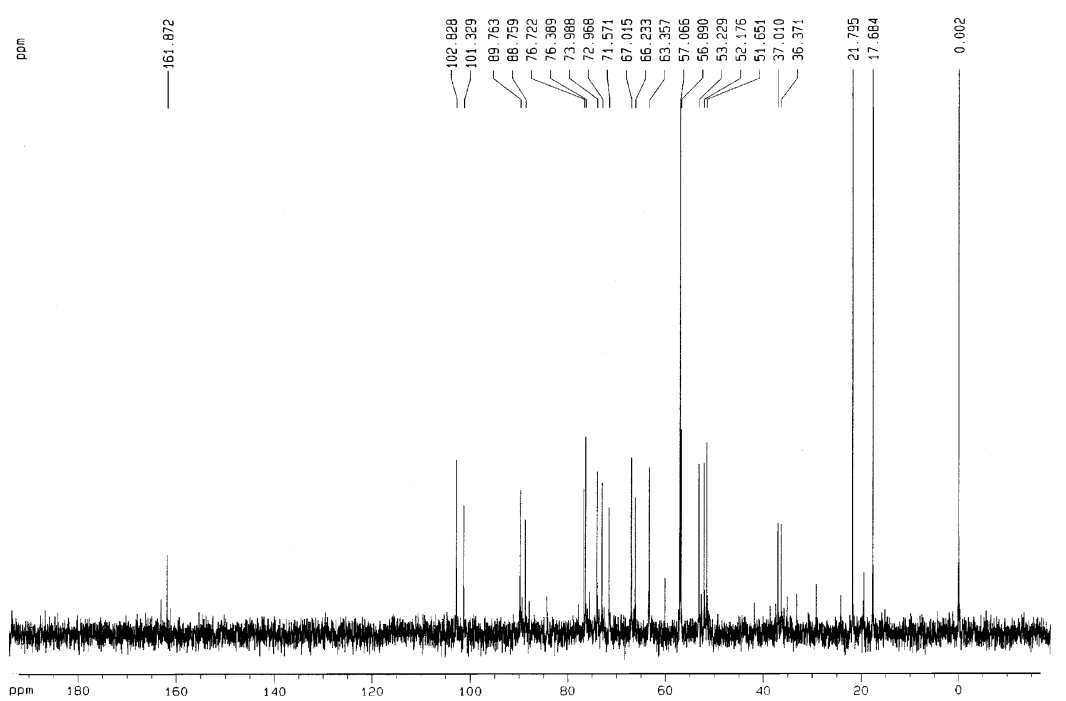

Fig. 4 The ${ }^{13} \mathrm{C}-\mathrm{NMR}$ analysis of the new antibiotic.

Table $2{ }^{13} \mathrm{C}-\mathrm{NMR}$ date of the new antibiotic*

\begin{tabular}{cccccc}
\hline Position & $\delta$ (ppm) & Position & $\delta$ (ppm) & Position & $\delta$ (ppm) \\
\hline 1 & 53.2 & $1^{\prime}$ & 101.3 & $1^{\prime \prime}$ & 102.8 \\
2 & 36.3 & $2^{\prime}$ & 51.6 & $2^{\prime \prime}$ & 72.9 \\
3 & 52.1 & $3^{\prime}$ & 37.0 & $3^{\prime \prime}$ & 56.8 \\
4 & 88.7 & $4^{\prime}$ & 67.0 & $4^{\prime \prime}$ & 71.5 \\
5 & 76.7 & $5^{\prime}$ & 76.3 & $5^{\prime \prime}$ & 73.9 \\
6 & 89.7 & $6^{\prime}$ & 63.3 & $6^{\prime \prime}$ & 66.2 \\
& & & & $\mathrm{CONH}_{2}$ & 161.8 \\
\hline
\end{tabular}

* Internal standard: DSS. clinically important bacteria, although it is less active than tobramycin.

\section{Discussion}

For studying the role of the putative dehydrogenase TacB, we constructed the $\operatorname{tac} B$ in-frame deletion mutant $S$. tenebrarius $\operatorname{tac} B^{-}$. TLC bioautography showed that the mutant strain produced a new antibiotic. After isolation and purification, the structure of the new antibiotic was further determined as 3'-deoxy-carbamoylkanamycin C by MS and NMR analysis.

The gene downstream of $t a c B$ is $t a c A$. The intergenic region between $\operatorname{tac} B$ and $t a c A$ contains two palindromic 


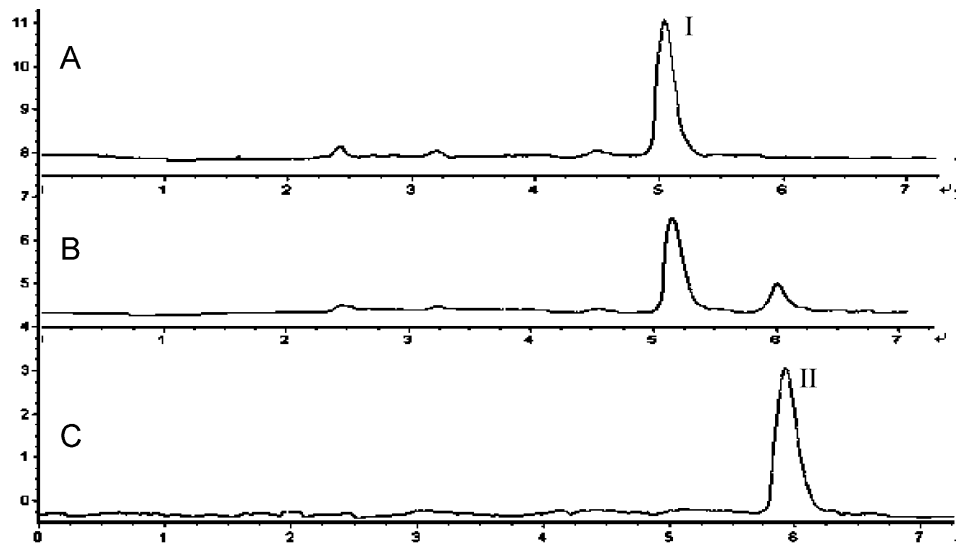

Fig. 5 HPLC-ELSD analysis of the isolated compound from tacB disruption strain $S$. tenebrarius tac $B^{-}(A)$, complementary strain $S$. tenebrarius $\operatorname{tac} B^{-}-\operatorname{tac} B(B)$, wild-type strain $S$. tenebrarius $H 6$ (C), where I correspond to 3'-deoxycarbamoylkanamycin $\mathrm{C}$ and II correspond to carbamoyltobramycin.

Table 3 Comparison of MICs between 3'-deoxycarbamoylkanamycin $\mathrm{C}$ and tobramycin

\section{$\mathrm{MIC}(\mu \mathrm{g} / \mathrm{ml})$}

\begin{tabular}{lcc}
\cline { 2 - 3 } \multicolumn{1}{c}{ Organism } & $\begin{array}{c}\text { 3'-deoxy- } \\
\text { carbamoylkanamycin C }\end{array}$ & tobramycin \\
\hline Escherichia coli & 16 & 2 \\
Bacillus subtilis & 8 & 4 \\
Staphylococcus aureus & $\geqq 32$ & 4 \\
B. proteus & 8 & 4 \\
Pseudomonas aeruginosa & $\geqq 128$ & 16 \\
B. pumilus & 16 & 1 \\
\hline
\end{tabular}

sequences (GGGCCGGGCGTCGGCCCCG; CACCGGTTCCTCACACCGGTT) that may form stem-and-loop structures in the RNA, which might act as transcription terminators of readthrough transcripts from genes upstream $t a c B$. This may reduce the chance of polar effects or additional mutations in the disruption strain, which was demonstrated by the integration of an intact $\operatorname{tac} B$ gene. By performing the restoration of the intact $t a c B$ gene back into the $\triangle \operatorname{tac} B$ strain, carbamoyltobramycin production was partially restored, this ruled out the possibility of a polar effect and proved that the production of $3^{\prime}$-deoxycarbamoylkanamycin $\mathrm{C}$ in $S$. tenebrarius $\operatorname{tacB}^{-}$was due to the loss of $\operatorname{tac} B$ function.

TacB was $76 \%$ identical to the KanI in the kanamycin biosynthetic gene cluster [7], was similar to the BtrQ (59\%) in butirosin biosynthetic gene cluster [26], ParQ (56\%) in paromomycin gene cluster, and NeoG (54\%) in neomycin biosynthetic gene cluster [11]. After bioinformatic analysis, ${ }^{20} \mathrm{GSGASG}^{25}$ sequence was found in TacB. This dinucleotide binding motif of the Rossmann fold (GXGXXG) was conserved in dehydrogenases from different Streptomyces, which suggested the function of TacB as a dehydrogenase. Our result not only supported this hypothesis but also clarified the specificity of this enzyme as $6^{\prime}$-dehydrogenase in tobramycin biosynthesis. The structural difference between 3'-deoxycarbamoylkanamycin $\mathrm{C}$ and carbamoyltobramycin is that the former has a 6-hydroxyl group while the latter has a 6-amino group. The TacB is responsible for reducing the $6{ }^{\prime}$-hydroxyl group of paromamine to a ketone group, then enabling the putative aminotransferase TacC to form neamine. Then, neamine is catalyzed to carbamoyltobramycin [4]. This is the first gene identified responsible for aminoglycoside biosynthesis after the formation of paromamine.

The new antibiotic $3^{\prime}$-deoxy-carbamoylkanamycin $\mathrm{C}$ is active against some common bacteria, although it is less active than tobramycin. However, the toxicity of $3^{\prime}$-deoxykanamycin $\mathrm{C}$ is lower than tobramycim $[16,27]$.

In summary, two major outcomes have been achieved. Firstly, we identified that $\mathrm{TacB}$ is a $6^{\prime}$-dehydrogenase, secondly, we got a new antibiotic, 3'-deoxycarbamoylkanamycin $\mathrm{C}$, by manipulating the biosynthesis through gene inactivation of $\operatorname{tac} B$. The strategy of gene inactivation and generation of new derivatives without chemical synthesis is a promising method and a step forward to the development of new antibiotics in order to overcome problems of infections caused by multi-resistant pathogens. 
Acknowledgement This work was supported by the national 863 foundation of China (No.2006AA02Z234).

\section{References}

1. Swan SK. Aminoglycoside Nephrotoxicity. Semin Nephrol 17: 27-33 (1997)

2. Pissowotzki K, Mansouri K, Piepersberg W. Genetics of streptomycin production in Streptomyces griseus: molecular structure and putative function of genes strELMB2N. Mol Gen Genet 231: 113-123 (1991)

3. Ota Y, Tamegai H, Kudo F, Kuriki H, Takeshita AK, Eguchi T, Kakinuma K. Butirosin-biosynthetic Gene Cluster from Bacillus circulans. J Antibiot 53: 1158-1167 (2000)

4. Kharel MK, Basnet DB, Lee HC, Liou K, Woo JS, Kim BG, Sohng JK. Isolation and characterization of the tobramycin biosynthetic gene cluster from Streptomyces tenebrarius. FEMS Microbiol Lett 230: 185-190 (2004)

5. Unwin J, Standage S, Alexander D, Hosted Jr. T, Horan AC, Wellington EM. Gene cluster in Micromonospora echinospora ATCC15835 for the biosynthesis of the gentamicin C complex. J Antibiot 57: 436-445 (2004)

6. Kharel MK, Basnet DB, Lee HC, Liou K, Moon YH, Kim JJ, Woo JS, Sohng JK. Molecular cloning and characterization of a 2-deoxystreptamine biosynthetic gene cluster in gentamicin-producing Micromonospora echinospora ATCC15835. Mol Cells 18: 71-78 (2004)

7. Kharel MK, Subba B, Basnet DB, Woo JS, Lee HC, Liou K, Sohng JK. A gene cluster for biosynthesis of kanamycin from Streptomyces kanamyceticus: comparison with gentamicin biosynthetic gene cluster. Arch Biochem Biophys 429: 204-214 (2004)

8. Huang F, Stephen FH, Mironenko T, Spiteller D, Li Y, Spencer JB. The neomycin biosynthetic gene cluster of Streptomyces fradiae NCIMB8223: characterisation of an aminotransferase involved in the formation of 2deoxystreptamine. Org Biomol Chem 3: 1410-1419 (2005)

9. Subba B, Kharel MK, Lee HC, Liou K, Sohng JK. The ribostamycin biosynthesis gene cluster in Streptomyces ribosidificus: Comparison with butirosin biosynthesis. Mol Cells 20: 90-96 (2005)

10. Kharel MK, Subba B, Lee HC, Liou K, Sohng JK. Characterization of L-glutamine: 2-deoxy-scyllo-inosose aminotransferase $(\mathrm{tbmB})$ from Streptomyces tenebrarius. Bioorg Med Chem Lett 15: 89-92 (2005)

11. Kudo F, Yamamoto Y, Yokoyama K, Eguchi T, Kakinama K. Biosynthesis of 2-deoxystreptamine by three crucial enzymes in Streptomyces fradiae NBRC 12773. J Antibiot 58: 766-774 (2005)

12. Kudo F, Kawabe K, Kuriki H, Eguchi T, Kakinuma K. A new family of glucose-1-phosphate/glucosamine-1phosphate nucleotidylytransferase in the biosynthetic pathways for antibiotics. J Am Chem Soc 127: 1711-1717 (2005)
13. Sambrook J, Fritsch EF, Maniatis T. Molecular cloning: A laboratory manual, 2nd ed. Cold Spring Harbor Laboratory, New York (1989)

14. Xia HZ, Wu S. Construction of DNA transfer system of Streptomyces tenebrarius. Wei Sheng Wu Xue Bao 42: 181-185 (2000)

15. Kieser T, Bibb MJ, Buttner MJ, Charter KF, Hopwood DA. Practical Streptomyces Genetics. Norwich: John Innes Foundation (2000)

16. Liu H, Xiong ZG. Studies on a new component of nebramycin, 98-23-Isolation, structure elucidation and biological activities. Chinese J Antibiot 26: 81-84 (2001)

17. Du Y, Li TB, Wang YG, Xia HZ. Identification and functional analysis of dTDP-glucose-4,6-dehydratase gene and its linked gene cluster in an aminoglycoside antibiotics producer of Streptomyces tenebrarius H6. Curr Microbio 49: 99-107 (2004)

18. Bao $\mathrm{K}$, Hu Z, Zhou $\mathrm{X}$, Zhou Q, Deng Z. A E. coli/Streptomyces shuttle cosmid vector used in conjugation. Chin Sci Bull 40: 1440-1444 (1995)

19. Bierman M, Logan R, O’Brien K, Seno ET, Rao RN, Schoner BE. Plasmid cloning vectors for the conjugal transfer of DNA from Escherichia coli to Streptomyces spp. Gene 116: 43-49 (1992)

20. Koch KF, Davis FA, Rhoades JA. Nebramycin: Separation of the complex and identification of factors 4,5 , and $5^{\prime}$. J Antibiot 26: 745-751 (1973)

21. Hong LY, Chen Y, Chen GB, Zhou MH. Content determination of tobramycin by HPLC-ELSD method. Chinese J Antibiot 30: 662-664 (2005)

22. National Committee for Clinical Laboratory Standards. Methods for dilution antimicrobial susceptibility tests for bacteria that grow aerobically: approved standard M7-A. National Committee for Clinical Laboratory Standards, Villanova, Pa. (1991)

23. Koch KF, Rhoades JA, Edward WH, Ernest W. Carbon-13 nuclear magnetic resonance spectral analysis of tobramycin and related antibiotics. J Am Chem Soc 96: 3300-3305 (1973)

24. Brunker P, Rother D, Sedlmeier R, Klerin J, Mattes R, Altenbrchner J. Regulation of the operon responsible for broad-spectrum mercury resistance in Streptomyces lividans 1326. Mol Gen Genet 251: 307-315 (1996)

25. Vara J, Lewandowska-Sharbek M, Wang Y, Donadio S, Hutchinson CR. Cloning of genes governing the deoxysugar portion of the erythromycin biosynthesis pathway in Saccharopolyspora erythraea. J Bacterial 171: 5672-5881 (1989)

26. Kudo F, Numakura M, Tamegai H, Yamamoto H, Eguchi T, Kakinuma K. Extended sequence and functional analysis of the butirosin biosynthetic gene cluster in Bacillus circulans SANK 72073. J Antibiot 58: 373-379 (2005)

27. Kondo S, Miyasaka T, Yoshida K, Iinuma K, Umezawa H Synthesis and properties of kanamycin $\mathrm{C}$ derivatives active against resistant bacteria. J Antibiot 30: 1150-1152 (1997) 